folk/ed. Derg, 2022; 28(1)-109. sayı

DOI: $10.22559 /$ folklor.2091

Araştırma makalesi/Research article

\title{
Argentinean Indigenous Culture in Animal Folktales
}

\section{Hayvan Halk Masallarında Arjantin Yerli Kültürü}

\section{Maria Ines Palleiro*}

\begin{abstract}
The history of Argentina as an independent nation began in 1816, although its foundation by the Hispanic conquerors took place in the XVIth century. This multicultural Latin American nation, located in the very south of the world, combines ancient vernacular indigenous roots with European cultural heritage, which arrived for the first time with the Hispanic conquest. The first foundation of Buenos Aires, the capital of Argentina, by the Spanish conqueror Pedro de Mendoza Argentina, took place in 1536. Nevertheless, indigenous people have been living in the Argentinean territory since ancient times. When the Spanish conquerors settled down in the country, they also bought African slaves, who obtained their freedom in 1813. Since the late XIXth, Century Argentina received new waves of European migration, mainly from Spain and Italy, but also from Asia, Africa, and from other South American countries. All this blend of cultures contributed to tracing a multi-
\end{abstract}

Geliş tarihi (Received): 11-11-2021 - Kabul tarihi (Accepted): 12-01-2022

* Ph. D. Buenos Aires University, National Council for Scientific Research, Argentina. Vice president for Latin America International Society for Folk Narrative Research. marinespalleiro@gmail.com. ORCID 0000-00026899-4238 
ethnical profile of Argentina, mirrored in folk narrative texts and collections.

Animal tales are highly relevant expressions of Argentinian folk narrative since they reflect such a blend of indigenous and European cultures.

Keywords: Argentina folk tales, local culture, interculturality, acculturation, fairy tale and culture

\section{Öz}

Bağımsız bir ulus olarak Arjantin'in tarihi, 1816'da başlatılmaktaysa da İspanyol fatihler tarafından kuruluşu XVI. Yüzyıla kadar uzanır. Dünyanın en güneyinde yer alan bu çok kültürlü Latin Amerika ulusu, ilk kez Hispanik fethi ile gelen Avrupa kültürel mirası ile eski yerel yerli köklerin birleştiği bir ülkedir. Arjantin'in başkenti Buenos Aires'in ilk kuruluşu, İspanyol fatih Pedro de Mendoza Arjantin tarafından 1536 yılında gerçekleşti. Bununla birlikte, yerli halk eski çağlardan beri Arjantin topraklarında yaşamaktaydı. İspanyol fatihler ülkeye yerleştiğinde, 1813'te özgürlüklerini elde eden Afrikalı köleleri de satın aldılar. XIX. yüzyılın sonlarından bu yana Arjantin, başta İspanya ve İtalya'dan, ayrıca Asya ve Afrika ve Avrupa'dan ve diğer Güney Amerika ülkelerinden yeni göç dalgaları aldı. Tüm bu kültür karışımı, halk anlatı metinlerinde ve koleksiyonlarında yansıtılan Arjantin'in çok ırklı profilinin izini sürmeye katkıda bulunmuştur.

Arjantin halk anlatısı içindeki hayvan masalları, yerli ve Avrupa kültürlerinin karışımını yansıttıkları için son derece ilginç veriler yansıtmaktadır. Makalede bu anlatılardaki karma kültürel yapı, metin analiz yöntemleriyle saptanmıştır.

Anahtar sözcükler: Arjantin halk masalları, yerel kültür, kültürlerarasılı, kültürleşme, masal ve kültür

\section{Introduction: Animal tales and belief narratives}

To deal with Argentinean animal folktales, it is worth characterizing Folklore and folk culture. According to Roger Abrahams (1971:16), folklore is the sum of all traditional expressions and implementations of knowledge operating within a community, comprising an embodiment of social beliefs. Such characterization underlines the role of beliefs in all traditional expressions, including folk narratives. Folk narratives, as verbal expressions of social identities, may be either highly codified items such as folktales and fairy tales, or simply codified ones, such as legends and anecdotes. Many animal tales show a mixture of these different folklore genres in a polyphonic message, in which fictional creatures cross the boundaries of belief discourse. In Argentinean folktales, in which fairies do not exist, there is an interweaving between animal tales, marvelous tales and belief narratives such as legends. Linda Dégh (2001) stresses that all legends are based on beliefs, to the extent that she considers the term "belief legend" as a pleonasm. All these narrative genres are closely related to daily experiences and beliefs in the societies in which they circulate (de Blécourt 2012), and serve as reaffirmations of commonly held values of the group to whose tradition they belong (Tangherlini 1990). These considerations reveal how folk narrative 
patterns change constantly while responding to the exigencies of different societies. From this standpoint, I will focus attention on those narratives which explore the boundaries of historic experience with the cognitive modality of belief, considered as a modal expression in which the true value of discourse depends on social consensus (Greimas \& Courtès 1982; Palleiro 2008). According to my classificatory goal, such an interweaving between different narrative genres can be observed in folk narrative expressions such as animal tales.

Animal tales are narrative expressions of the most diverse cultures. They can be found both in early Eastern cultures, in Greco-Roman antiquity, in the Christian Middle Ages up to the present times in following the itineraries which show intercultural crossroads between Eastern and Western traditions (Palleiro 1998). Such crossroads can be found as well in Argentinean animal tales, which reflect the intertwining between European and vernacular indigenous cultures, in an original blend which is the distinctive feature of Argentinian identity.

The main protagonist of Argentinean animal tales is neither the wolf nor the bear or jackal, as in European and Asian folktales, but the fox, who is the protagonist of two different cycles. In one of them, the fox assumes the role of a large and foolish animal (such as the one attributed in the International Index of Classification of Folktales by Antti Aarne, Stith Thompson and Hans Uther ATU Index to the wolf), and in the other one, he plays the part of the smaller, cunning animal threatened by the bigger and mightier tiger. In the cycle of "The Fox and the Tiger," the cunning fox defeats the tiger, representing the victory of the intelligence over the force. In the other one, the fox is mocked by smaller animals, representing as well the victory of the cleverness over the force. Other characters of Argentinean animal tales belong to the vernacular fauna. Many of them have local or indigenous names, such as the "armadillo" (quirquincho or peludo) or "the ostrich" (suri, in indigenous Quechua language). The role of the fox's enemy is played not only by the tiger, but also by the armadillo, the lion, or even by different local birds.

In animal tales, the dominant rhetorical strategy is personification, whereby animals can think and speak in human language. In indigenous cultures, the human embodiment of animals is connected with a worldview in which they are considered as representations of supernatural forces. In Hispanic tradition, folk narrators give human names to the animals. In this way, the fox is called "John," his wife is "Jane" and their children are "the Johnnies." This name is also well spread in Latin America and particularly in Argentina, where the fox also receives the vernacular affective diminutive of "Juancho. "

In the Preface to the main Folk Narrative Collection, Cuentos y leyendas populares de la Argentina (Argentinean popular folktales and legends), Berta Vidal de Battini (1980-1984 ) points out that animal folktales such as the ones of the fox cycle arrived in Argentina with Spanish conquerors in the early $16^{\text {th }}$ century, and such cultural heritage is reflected in the way in which narrators name the fox Juancho, and other vernacular animals, like the tiger, as Simon, and a local bird as Alonsito. ${ }^{1}$ Nevertheless, it is worth considering that animal tales belonged as well to indigenous vernacular cultures, in which they have been told since ancient times. 
In short, animal tales can be characterized as a folk narrative genre whose protagonists are animals. These folktales reflect the atmosphere of rural life through the humanization of the vernacular fauna (Kovacci 2000), and such personified animals carry out a series of actions articulated in sequences, which take place in a fictional world. Each version is organized according to narrative patterns or "matrices" stabilized in the diachronic transmission process, which includes scriptural registers and recreations.

In this article, I deal with a vernacular version of an animal tale collected in Argentina, whose transformation of a folk matrix connected with local beliefs, expresses the differential identity of vernacular cultures. The vernacular variants of animal tales mirror the distinctive features of the Argentinian context - both of the landscape, with its vegetation of "pencas" and "jarillares", in a space surrounded by hills, and of the local fauna, whose animals receive indigenous names, such as "chilicote" (cricket), "jote" (bird of prey), "suri" (ostrich) and other ones, who appear as personified protagonists of the folktales, such as the abovementioned fox ("zorro") and the" quirquincho " (armadillo), his wife"the quirquincha" (female armadillo) and their offspring "the quirquinchitos"(baby armadillos).

The folktales have been classified into narrative matrices, which act, as I will explain below, as pretextual patterns sharing thematic, compositional, and stylistic features, with contextual transformations in different versions and variants that express the identity of different vernacular cultures of Argentinean regions, reflecting as well the personal style of each storyteller.

To sum up, animal tales can be characterized as a folk narrative genre whose protagonists are animals that reflect the atmosphere of rural life through the humanization of the vernacular fauna. Such personified animals carry out a series of actions articulated in sequences, which take place in a fictional world. Each version is organized according to narrative patterns or "matrices" stabilized in the diachronic transmission process, which includes scriptural registers and recreations.

\section{Details, matrices, alternative itineraries, and social beliefs in folk narrative}

From a formalist perspective, Jan Mukarovsky (1977) underlines the semantic relevance of apparently irrelevant changing details as the basic semantic units in folk art, and he also describes the structure of the folk text as a "mosaiclike" heterogeneous addition of such semantic units. In the constructive process of folktales, such details act as mnemonic tracks, which activate totally or fragmentarily thematic, compositional and stylistic features whose combination constitutes a folk narrative matrix. This concept of "narrative matrix" adds to the thematic regularities classified into tale types, structural, and rhetoric issues (Palleiro 2004, 2018). It is worth remembering the characterization of the tale type provided by Thompson (1946: 415) as "a traditional tale that has an independent existence" that may be told," as a complete narrative and does not depend for its meaning on any other tale". Each tale type may consist of only one or of a combination of thematic minor units or "motifs", which are the building blocks within the plot-patterns, repeated in different folktales of different 
times and places. These tale types have been thematically described and classified in an international index by Antti Aarne and Stith Thompson (1961), recently updated by Hans Uther (2004). The folk narrative matrix, identified through intertextual comparison of folk narrative versions, constitutes a pre-textual pattern stored in the memory of folk narrators. Each pre-textual pattern, comprising thematic, compositional and stylistic features stabilized along the diachronic process of oral (and written) tradition, can be transformed in each new narrative context through the addition, suppression, substitution, or displacement of these changing details, generating alternative itineraries in different communicative situations. In this way, each narrative matrix acts as a germinal nucleus of versions and variants displayed in different contexts (Palleiro 2004, 2018). The folktale's genesis is thus based on the transformation of narrative matrices in new cultural environments, expressing the differential identity of each culture (Palleiro 2018) such as the Argentinian one. As aforesaid, the concept of "folk narrative matrix", rooted in Mikhail Bakhtine's characterization of discursive genres (Bakhtine 1982), adds to the thematic features, structural and stylistic ones. Thus, the transformation and of each matrix in different contexts is the basis constructive process or "genesis" of the folktale. Such transformation of the matrix makes room for different itineraries in diverse cultural environments, by means of changing details. From this standpoint, folktales can be considered as verbal expressions of social identity, sequentially organized in alternative versions of pretextual patterns or matrices, which show the blend between European and vernacular indigenous cultures. Animal tales are the first category in which folktales have been classified in the international classification by Hans Uther, being the other marvellous tales (tales of magic), religious tales, realistic tales, tales of the stupid ogre, anecdotes and jokes, and formula tales (Uther 2004).

In spite of this thematic classification, animal tales show a mixture with other folk narrative genres such as legends and other belief narratives, in a polyphonic message. Through the transformation of the aforesaid pre-textual patterns or "matrices" by means of additions, suppressions, substitution or displacement of changing details, animal tales include in their texture social beliefs bound to vernacular contexts (Palleiro 2018).

\section{The fox and the magic pot: Folktales and vernacular beliefs}

To show the intertwining between folktales and belief narratives, I will deal with a tale told by the Argentinean folk narrator Amalia Vargas, presented as a retelling of an oral version transmitted by her mother. Such version, whose title is "The fox and the magic pot", shares some thematic features with the narrative tale type number 1539 of the Aarne-ThompsonUther International Tale Type Index of Folktales (ATU), “Cleverness and gullibility". I will compare this version with a cosmogonic tale told by the vernacular narrator Horacio Castro, who belongs to the Omawaca culture of the same Andinean zone where Vargas was born. Such comparison is oriented to examine the blend of different folklore genres and to show how animal tales are interspersed with belief narratives. The aim is to point out the relevance of belief narratives in reframing folklore genres and to highlight their flexible boundaries. 
Amalia Vargas is a vernacular narrator born in Ciudad Perico, in the province of Jujuy, located in the Andinean zone of Northwestern Argentina, next to the Omawaca creek. She finished university studies in Folklore and Visual Arts and she presented herself as a member of the Quechua-Aymara community. She narrated this version in Buenos Aires city, in March 2020 , in a performative display, in which she used corporal resources to illustrate her verbal discourse. The texture of this version highlights the hallmark of her personal style, expressing as well the social beliefs of her own community. In the conversation in which she inserted the narrative, Vargas emphasized the relevance of the gender perspective. She thus constructed the version as warning discourses transmitted by her mother in order to prevent women from the possibility of falling into the deceptions accomplished by male tricksters.

\section{The narrative text}

Maria - Hi, Amalia, could you please tell me the tale of the fox? But first introduce yourself ...

Amalia- I am Amalia Vargas, I am Quechua from the Chibcha nation, from the border with Bolivia, from the mountains.

Well, I'm going to tell you a story my mom told me. The protagonist is John the fox, who he is one of the most mischievous animals, right? He is a trickster; he is the one who always makes fun of people.

Hey, my mom says that, in the past, the fox was always dressed in brown, and that he was always wearing a brown scarf, and a little brown hat. So ... uh ...Because, once upon a time, in past times, some people were men during the day, but in the evening and in the night, they became animals.

So, uh ... This fox was a man, whose job was to be a salesman, he sold all kind of stuff, right? For instance, he sold pots.

And it is said that one day, he was going to sell pots, and he dug a hole in the ground, in order to put there the embers.

So, he said: -Now, I'm going to put the embers into a hole, into the soil, in order to hide the embers, and then I'm going to pour water into the pot. Firstly, I'm going to heat the water, and then I'll put the pot I want to sell right over the embers, but the embers will remain hidden in the soil! And so, people won't realize that, right?

[It's] like putting this here, but it's hot down below, like this [Amalia Vargas held a kettle containing hot water, which was placed on a table, and then she put a dish below"]

And then the water will boil, thanks to the hidden embers, but people will think that the pot is a magic one.

So, when people will come, I'm going to do like this ... eeh ...I'm going to speak out loud, and even to shout, so that they all will come, and I'm going to sell them the pot as a magic one.

He did so, and he also put a set of clay pots stacked one on top of the other, and then he went to the fair.

Once arrived there, he started saying to the people, in the fair: -Come on, come and see this, come on! Here, I have a pot that doesn't need firewood, you don't have to fetch water from the river any more, you won't have to walk round the mountains, and you won't have to light the fire! This pot is magic; you just have to pour the water into the 
pot and then start walking around, in small circles!

So ... uh ... the fox kept on saying -Well, let the people touch the pot, so that they can see that the water is hot, and that it is boiling, and in that way they will believe that the pot is a magic one, and that it does not need firewood!

And, so, he started saying: - Hirve, ollita; kirpe, ollita! Hirve, ollita; kirpe, ollita! (Boil, little pot; boil, little pot!)

That was like a sort of charm.

And that he did a few laps and, in a little while, smoke and bubbles began to come out, right?

And that the water heated up. [The narrator moves in circles around an imaginary object]

So, all the people wanted to buy the pot, and one person bought it, because they all were saying: -Oops, we'll not have to buy any more wood, we will not have to go to fetch firewood in the forests, in the mountains!

So what did this person, the customer, do?

When he arrived home, he put the pot on the floor, and he began saying: "Boil, little pot; kirpe, ollita! - just going around; like a fool.

But nothing! The pot remained cold, just, as it was.

And the water remained also cold, and just that.

And that was the trick. That was the mockery the fox did, right? Since he was a person during the day, a person who made fun of people, selling those things, right? , mocking at the people.

And that the people could realize that it was the fox, because he was always wearing his brown scarf.

MIP-Wow, it's beautiful!

As aforesaid, this version is structured according to a standardized pattern, diachronically set in an oral traditional process, which may include as well scriptural registrations as the one here provided. Each narrative pattern or "matrix", comprising thematic, compositional and stylistic features, set along such diachronic transmission, is updated at each new contextual narrative situation (Palleiro 2004, 2018). As abovementioned, the semantic content of this matrix shares thematic features with ATU tale type No. 1539, whose thematic description, as provided by Aarne-Thompson, is:"The youth sells pseudo-magic objects and animals (...) The self-cooking pot. Uther provides a more detailed thematic description, in which he includes, as a variant, the following reference: "In some versions, the farmer sells his adversaries supposedly wonderful objects, e.g. (...) a pot that cooks by itself (Uther 2004, II: 276). These thematic topics do not refer to the narratives classified in the universal indices as "animal tales" (types 1-299), but to the ATU category of "Anecdotes and jokes / Tales about a man" (types 1525-1724). ${ }^{2}$ Such thematic features also correspond to the motif K 112.1 from Stith Thompson's motif index, "A pot that cooks by itself". Since the matrix includes a parody of magic objects, it also presents thematic elements in common with ATU's types classified as "tales of magic" (types 300-749), such as ATU 565 "The magic mill". This combination of different types, motifs, topics and categories shows the relativity of all typological classification, as well as the flexible itineraries of folk narrative matrices. 
Similar versions can be found in the Hispanic, Galician and Catalonian indexes of Boggs, Noia Campos and Oriol-Pujol under the same tale-type number, revealing the presence of the same tale types in the Iberian Peninsula. Such presence of this matrix in European indexes confirms the blend of Hispanic cultural elements with vernacular ones in Vargas's repertoire. In fact, this narrative pattern is bound to European cultural heritage, mixed up with elements of indigenous Latin American traditions such as the Quechua one, in a resemantization process of the matrix according to Northwestern Argentinian vernacular cultural values. According to such cultural values, the focus of the narrative deals, on one hand, with warning against deception in a context in which trickery is an important ability to survive in difficult contexts. On the other one, the deception is linked with a tension between essence and appearance that is part of a local worldview according to which men and animals, good and evil are not quite opposites but complementary aspects of daily life.

Along with these thematic features associated with ATU 1539, as well as with ATU,

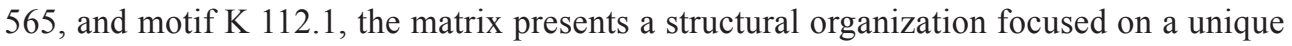
macrosequence. Such macrosequence is divided into two episodes: the one of planning the deception and the one of consummating it. The rhetoric construction is based on the parodic use of a charm. The axis of this thematic, structural and rhetoric pattern is connected with trickery used to sell pseudo magic objects and with the antithetical tension between appearance and essence. Such thematic, structural and stylistic elements that constitute the narrative matrix are part of the repertoire of this narrator, which includes different versions dealing with trickery, in the vernacular setting of the Argentinian Northwest. I deem the folk repertoire as the set of tales stored in the collective memory of a certain community and in the individual memory of the folk narrator, aesthetically reframed with a personal style which is the hallmark of the authorship of discourse (Bauman 2004, Palleiro 2006). This reframing procedure consists in an individual poetic work of selecting, combining and recreating traditional thematic topics, as well as structural and rhetoric forms that constitute the narrative knowledge of a social group. Such poetic work shows the personal style of Amalia Vargas, who recreated traditional narrative patterns transmitted by her mother.

The semantic content of this narrative includes the topic of the metamorphoses of animals linked with deception, accomplished in this case by the fox, which is said to be transformed into a man during the day. Thus, the main discursive strategy is the personification of the fox, who is presented, in his diurnal transformation, as a salesman, through a descriptive rhetoric strategy. Such description, anchored in the clothing - with a predominance of chromatic rhetoric that establishes an analogy between the brown colour of the fox's head, the brown hat, the brown tail and the brown scarf - gives rise to the incorporation of the simultaneous dimension of space in the sequential development of the narrative actions. Hence, the narrator presents the topic of deception as closely linked to the tension between essence and appearance, which is the axis of the narrative matrix.

In this version, the deception consists of a sale of a pot that is said to have the magical power of boiling by itself without any fire, with the sole invocation of this object, accompanied by the order to boil. In this way, the protagonist manages to sell the pot, having previously 
lit on the fire and hidden the embers under the ground. The focus of the thematic content of the matrix is the trick and the disguise. On a structural level, the narrative is articulated as an independent episode of a series of deceptions, each one of which is organized around a single macrosequence, divided into two microsequences: the one of the preparation of the trick, and the one of the accomplishment of the deception. A relevant stylistic resource, in addition to the personification, is the antithesis between the true properties of such pot and those enunciated by its owner, along with the invocation to the pot. Such invocation enhances, in a parodic way, the performative force of language, which is the basis of charms and magic formulae. The formula used in this case is: "Boil, pot; kirpe, ollita! - ( Hirve, ollita; kirpe, ollita! - “), emphasized by the duplication of the same thematic topic in two different linguistic codes: in Spanish and in vernacular Quechua language. Such formula contains, as aforesaid, an invocation to the magic object, represented in this case by the pot, personified as a receiver. Such personification of the magic object as a second person who acts as the addressee of the formulaic message is typical of the magic function of language described by Jakobson (1964). The syntactic and lexical construction is thus based on a sequential repetition of words and structures, fixed in a formulaic configuration. Between the elements of incantation, Bozóky (2003) lists the naming of the object of the charm (the pot), the conjuration (the command of boiling); the nomination of the helping powers (such as the pot) and the dramatization, connected in this example with the acting out of the scene performed by the possessor of these false magic objects. Like Pócs, also Bozóky calls attention to the vocal effects of incantations - rhythmical forms, rhymes, alliteration, repetition, anaphora, "stream of words" - such as the ones used here, even in Quechua languages. This version presents both rhythmical forms and a sequential repetition of words and actions with a performative effect is as well a distinctive feature of ritual discourse (Rappaport 1992). The power of words in incantations, underlined by Vargas herself in a metapragmatic clause ("That was like a sort of charm"), consists in an ensemble of ritual procedures including gestures such as the one of going round in circles or holding the tail of an animal, which the narrator achieves in a verbal and corporal performance, oriented to provoke the action of boiling. Such corporal movements are, along with the intonation of the repetitive formulae, essential issues for the performative efficacy of the message. Words intensify the request to the object contained in the charm as linguistic tools, consisting both of syntactic and semantic strategies, displayed with rhetorical procedures such as repetitions and invocations, with the mediation of supernatural forces (Pócs 1999) attributed to personified objects such as the pot. All these strategies can be identified in this version, oriented to the discursive construction of a parodic charm. The development of narrative action generated by this formula is indeed parodic since, instead of accomplishing the requested act and of demonstrating the efficiency of the formulaic words to bring wealth to the owner, the possessor of the pseudo-magic object is cheated every time. In this way, the formula has not only a stylistic but also a structural function in the narrative plot. Actually, the formula acts as a leit-motif with the power of causing the main actions of the narrative sequence. The axis is the false power of magic objects to transform the hard daily reality of vernacular people who go to the fair to buy goods. 
Connected with the ironic use of the formulaic style, other discursive strategies are comic resources such as irony, bordering on mockery, and the description of the protagonist's appearance, which acquires special importance, since it is associated with the topic of the metamorphosis. Descriptions and allusions to the geographic landscape of "the mountains" mentioned by the narrator and to the cultural landscape of local beliefs contextualize the folk matrix in the Argentinian Northwest, creating an effect of reality. Another relevant discursive strategy is the dialogical counterpoint, enhanced by gestures, which gives a theatrical nuance to the narrative action.

The version, whose climax is deception, is presented as an argumentative examples of a scam accomplished through trickery, with a ritual significance connected with local vernacular beliefs.

\section{The fox as a mythical animal: An intertextual comparison}

In Northwestern Argentinian vernacular cultures, the fox is an emblematic animal, linked with indigenous beliefs in the Pachamama, a Quechua earthly divinity. As anticipated, in animal tales, the main rhetorical strategy is the personification of different animals of the local fauna, according to which they can think and speak. This personification is connected with local worldviews, such as the one of the Quechua cultures, in which the fox is considered a demiurge, that is to say, an intermediary between the world of men and the realm of the supernatural that he embodies and represents. Such worldview is based on a strong connection between the human and the supernatural semantic domains.

The demiurgic role of the fox is also mentioned in mythical narratives such as the one entitled "The fox, the first of all the animals" narrated in 2002 by Horacio Castro, who belongs to the indigenous culture of the Omawacas, placed in a zone of Jujuy near to that where Amalia Vargas was born. The action is placed in an original time, being this a distinctive feature of mythical discourse. I

In this version, in which Castro, aged over 40, presented the fox as a demiurgic animal, the narrative plot was located in the very moment of the creation of the world. According to Castro's discourse, the world was created by the Pachamama. a feminine goddess identified with Mother Earth, who gave rise to all living beings. As this narrator refers in this cosmogonic tale, in the origin of the world, the Pachamama, who created the sun, the moon and all living creatures, created also the fox, who was "the main, the cutest, the largest, the dominant animal" and "the smartest of all", because she gave him all qualities. Therefore, the other animals complained to her and she gradually removed different attributes from the fox, to distribute them between other animals:

I'll tell you what has happened long ago, in times of the creator of everything, the female goddess, the Pachamama...

It is said that long, long time ago, the Pachamama created everything. She created the sun, with the fire she took from inside her. She created as well the stars and the moon and the snow on the hills. She created the water, she created everything. And she 
created all the animals, in the beginning. And the cutest, the dominant animal was the fox, and all the other animals were smaller than him.

Well, the other animals started complaining, and then the Pachamama decided to give to the other animals some of the attributes that the fox had more than enough, because, of course, the fox was the only to fly, the only to swim, the only to run. In this way, birds began to fly; fishes began to swim, and so on.

The fox was still the first of all the animals because he preserved his intelligence (...) Well, the fox was as much not worried, because he had still his intelligence, while the others had not After all, the fox was still cute. He was thin, yes he was, but he was still so cute, and besides he also was the smartest of all.

But at last, an ugly monkey, who was the last of all, came to ask the Pachamama to give something to him. And this monkey was the last one, the ugliest one. This ugly monkey, the last one, this was the man, the ugliest of all the animals. But the Pachamama had compassion, she was full of mercy towards this ugly monkey, but she had no more gifts. So, what did she take away from the fox? She took away his intelligence, and she gave it to the man. So the man who was the last of all, the one who was the unhappiest of all, in this way became the one who dominated everything, the one who gradually subdued all. And the poor fox was left with less intelligence, and he got into trouble with the man, who began destroying nature. So, in this way, the fox he was forced to trickery and to deceit in order to survive, he was compelled to take advantage of some actions achieved by the man, who began destroying Nature.

So the fox remained still cunning, still cute, but he was forced to survive in a world commanded by the man.

The climactic point of this tale, connected with the worldview of Omawaca vernacular culture, is the cosmogonic reference to the act of creating the world undertaken by the Pachamama, and the moment in which she takes away the intelligence of the fox to give it to the man. As the narrative explains, from the moment in which this earthly divinity gave the main part of intelligence to the man, the fox "was forced to trickery and deceit in order to survive". In Castro's version, framed within the collective memory of the Omawaca culture, the fox was presented as metaphorical expression of the cultural identity of this community, whose members, as the fox, struggle to survive in a space threatened by men who don't care about Nature. Thus, "The fox, the first of all the animals" is an etiological narrative that explains the origin of the intelligence and the ability for trickery of the fox, linked with the original distribution of "gifts" by the Pachamama.

In the same way, as Vargas did in her narrative, also Castro presented in his discourse a cultural landscape of the Argentinian northwest, textualized in an animal folktale. In his narrative, he combined legendary and mythical speech, in an intertwining with a fictional discourse that shows the textual blend of different folklore genres, which can be found as well in Vargas's version. This intertextual comparison shows the connection of animal tales regarding the fox with Vargas's narrative, which includes allusions to the man as an anthropomorphic transformation of the fox. Both Castro and Vargas underline the close relationship between animal and human semantic domains, which is one of the distinctive features of North-western Argentinian vernacular cultures. 
The topic of the transformations of men into animals is connected with the contrast between reality and appearance, and such antithesis is also the climactic point of the narrative series of animal tales, in which a weaker animal manages to defeat the stronger one. The allusion to circularity pointed out in the narrator's discourse ("It is always turning round, always circular") is close to ritual discourse. Actually, in a scientific contribution, Vargas herself pointed out the relevance of the Quechua Mullu or circularity in rites, dances and ceremonies of Andinean communities of the Argentinian Northwest to which she belongs (Vargas and Mendoza Salazar in Palleiro 2019: 205-213). All these intertextual connections reveal the resemantization of folk narrative matrices, due to vernacular beliefs.

To summarize, the fox acts as a metaphor of Quechua culture, in which the interaction between animals and human beings is a kernel point, since all of them have been created by the Pachamama, an earthly vernacular divinity. Due to the lack of care of the man towards animals and nature, the fox has been compelled to become a trickster, whose actions are narrated in Vargas's repertoire, in order to survive in a world commanded by the man.

\section{Final considerations}

This comparative approach to different versions of Argentinian animal tales revealed the permeability of folk narrative matrices towards contextual transformations dealing with belief narratives, mirroring vernacular worldviews. The distinctive features of these narratives is a serious warning against the damage to the natural ecosystem provoked by human actions. The animal world reflected in folktales could perhaps teach us to take care of the environment, in order to prevent global catastrophes such as new pandemic threats, earthquakes and another local and global natural disaster, such as the Covid pandemia, which was the context in which Amalia Vargas performed her narrative discourse.

Just to conclude, it is worth pointing out that this article offers a sample of a larger research sponsored by the National Council for Scientific and Technical Research (CONICET) regarding the intertwining between folktales and belief narratives in a larger corpus of Argentinian Märchen, which includes both animal and marvelous tales. In such research, based on the application of ethnographic method, I registered and analysed 22 narrative matrices of animal tales of different Argentinian regions. By means of intertextual comparison between folktales, legends, myths and personal narratives, I proved the contextual transformation of general matrices in different vernacular environments (Palleiro 2020). Nowadays, I am extending this comparative research to marvellous tales, in order to edit a complete collection of Argentinian Märchen, whose axis is the interweaving between tales and belief narratives in different folk narrative genres. 


\section{Endnotes}

1 "Alonsito" is the given human name of a local bird, the hornero ("oven bird") so called because her nest has the size of an oven.

2 This matrix is included in the tenth volume of Vidal de Battini's collection Cuentos y leyendas populares de la Argentina (Argentinian Popular folktales and legends) not in the section corresponding to "Animal tales" but in the one corresponding to "Popular characters and tricksters" under the numbers 2655 to 2838 whose protagonist is the Hispanic trickster Pedro Ordimán. This section includes a parodic version classified under the number 2655, "The pot of virtue," which alludes as well to a self-boiling pot. In this version, the trickster tells that such self-boiling pot is a miraculous one given by the Christian God to him as a special gift.

\section{References}

Aarne, A. and Thompson, S. (1961). The types of the folktale: A classification and bibliography. Helsinki, Finland: Academia Scientiarum Fennica.

Abrahams, R., (1971). Personal power and social restraint in the definition of folklore. Journal of American Folklore, 84 (331), 16-30.

Bakhtine, M., (1982). Estética de la creación verbal. México DF, México: Siglo Veintiuno.

Bauman, R., (2004). A world of other's words. cross-cultural perspectives on intertextuality. Oxford, United Kingdom: Blackwell, 2004.

Blécourt, W. de (2012). The problem of belief narratives: A very short introduction. Newsletter of the International Society for Folk Narrative Research, 6, 36-37.

Boggs, R., (1993[1930]). Index of Spanish folktales. Helsinki, Finland: Academia Scientiarum Fennica. Bozóky, E., (2003). Charmes et prières apotropaïques. Louvain, Belgique: Brepols.

Castro, H. (2020). El zorro, el primero de los animals. In (M. Palleiro. Ed.), Juan Zorro, el quirquincho y el tío tigre. Cuentos animalísticos y creencias sociales (pp. 374-375). Buenos Aires, Argentina: La Bicicleta.

Dégh, L., (2001). Legend and belief: dialectics of folklore genre. Bloomington, United States of America: Indiana University Press.

Greimas, A. and Courtés, J., (1982). Semiótica. Diccionario razonado de la teoría del lenguaje. Madrid, Spain: Gredos.

Jakobson, R., (1964). Closing statement: Linguistics and poetics. In (Th. Sebeok. Ed.) Style in Language (pp. 350-377). Massachusetts, United States of America: MIT Press.

Mukarovsky, J., (1977). Detail as the basic semantic unit in folk art. In J. Burbank and P. Steiner (Eds. and Translators), The Word and Verbal Art: Selected Essays (pp.180-204). New Haven, United States of America: Yale University, 1977.

Noia Campos, C., (2010. Catálogo tipolóxico do conto galego de tradición oral: Clasificación, antoloxía e bibliografía. Vigo, Spain: Servizo de Publicacións da Universidade de Vigo.

Oriol, C. and Pujol, J., (2008). Index of Catalan Folktales. Helsinki, Finland: Academia Scientiarum Fennica.

Palleiro, M., (1998). "La fiesta en el cielo." Cuentos populares de animales. Buenos Aires, Argentina: Del Sol.

Palleiro, M., (2004). Fue una historia real. Itinerarios de un archivo. Buenos Aires, Argentina: Instituto de Filología y Literaturas Hispánicas Universidad de Buenos Aires.

Palleiro, M., (2006). "Blancaflor, la hija del diablo": autoría y estilo en el repertorio de un narrador folklórico. Revista de Investigaciones Folclóricas, 21, 115-127. 
Palleiro, M., (2008) Yo creo ¿vos sabés? Retóricas del creer en los discursos sociales. Buenos Aires, Argentina: Facultad de Filosofía y Letras de la Universidad de Buenos Aires.

Palleiro, M., (2018). La dama fantasma. Los laberintos de la memoria en el relato folklórico. Buenos Aires, Argentina: La Bicicleta.

Palleiro, M., (2020) Juan Zorro, el quirquincho y el tío tigre. Cuentos animalísticos y creencias sociales. Buenos Aires, Argentina: La Bicicleta.

Pócs, E., (1999) Between the Living and the Dead. A perspective on witches and seers in the Early Modern Age. Budapest, Hungary: Central Europe University Press.

Rappaport, R., (1992). Ritual. In R. Bauman (Ed.), Folklore, cultural performance and popular entertainments. A Communications-centered Handbook (pp. 249-260). New York, United States of America: Oxford University Press.

Uther, H., (2004). The types of international folktales: A classification and bibliography, based on the system of Antti Aarne and Stith Thompson. Helsinki, Finland: Academia Scientiarum Fennica.

Tangherlini, T. (1990). It happened not too far from here. A survey of legend theory and characterization. Western Folklore, 49 (4), 371-390.

Thompson, S., (1946). The folktale. New York, USA: The Dryden Press..

Thompson, S., (1955-1958). Motif-Index of Folk-literature. Copenhagen, Denmark and Bloomington, US: Indiana University Press.

Vargas, A. and M. Salazar, D. (2019). El Mullu o la circularidad en las danzas tradicionales aymaras del altiplano boliviano y en las copleras humahuaqueñas del Noroeste Argentine. In m. Palleiro (Ed.), Del cuerpo narrado al cuerpo en movimiento. Folklore, danza y construcción narrativa de la alteridad (pp. 205-213). Buenos Aires: Casa de Papel.

Vidal de Battini, B., (1980-1984). Cuentos y leyendas populares de la Argentina I-IX. Buenos Aires, Argentina: Ediciones Culturales Argentinas.

Vidal de Battini, B., (1995). Cuentos y leyendas populares de la Argentina X. Buenos Aires, Argentina: Secretaría de Cultura Ministerio de Educación y Justicia. 